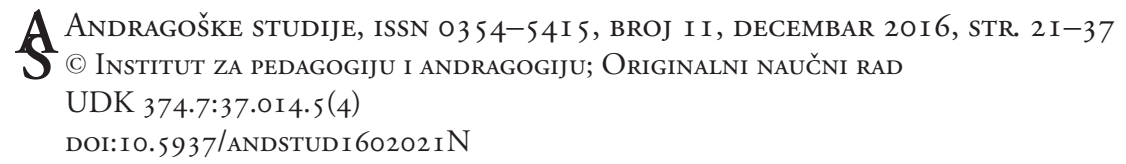

Ekkehard Nuiss $1^{1}$

Technical University of Kaiserslautern, Germany

Simona Sava ${ }^{2}$, Anca Luştrea ${ }^{3}$

West University of Timisoara, Romania

\title{
Internationalization of Research and Studies in Adult Education ${ }^{4}$
}

\begin{abstract}
There is a high need for formal provision for professionalization of adult educators at academic level (Research voor Beleid, 2008; European Commission, 2013b; CEDEFOP, 2013). In this paper, we explored the views of colleagues from ten universities from nine European countries who work together on developing the joint program on European Master in Adult Education (EMAE) as the European Doctoral School in Adult Education, in this way setting up the largest network of professionalization in adult education at European level. Our colleagues have been interviewed with the purpose of finding out about their motivation, expectations, the added value for their universities, and the outcomes and benefits of joining to such consortium. We also explored the obstacles and difficulties in designing and implementing the joint programs. Their reflections and experiences can be a source of inspiration for other universities interested in joining the consortium or setting up similar offers.
\end{abstract}

Keywords: globalization and international higher education, professionalization, adult education, joint programs, international cooperation in higher education.

\footnotetext{
${ }^{1}$ Ekkehard Nuissl, PhD is Professor at the Technical University of Kaiserslautern, Germany (nuissl@die-bonn. de).

${ }^{2}$ Simona Sava, PhD is Professor at the Department of Educational Sciences, West University of Timisoara, Romania (lidia.sava@e-uvt.ro).

${ }^{3}$ Anca Luştrea, PhD is Assistant Professor at the Department of Educational Sciences, West University of Timisoara, Romania (anca.lustrea@e-uvt.ro).

4 The research has been carried out within ESRALE - European Studies and Research in Adult Learning and Education, Project no. 540117-LLP-1-2013-1-DE-ERASMUS-EQMC. A first draft of the article has been presented at the 4th International Conference "The Role of higher Education in the Process of Professionalization of Adult Educators", ESREA-RENADET, Larnaca, 11-13.11.2015, and improved, based on the feedback of the participants.
} 


\section{Conceptual Preliminary}

The largest network for formal professionalization in adult education (AE) in Europe has been set up within the European Studies and Research in Adult Learning and Education (ESRALE), an ERASMUS curriculum development project running between 2013 and 2016.

"Adult Education" is defined as all kinds of further learning and teaching of adults, as it is covered by the category of "non-formal learning" in the documents of the European Union.

The aims of the project are threefold: to update and enlarge the already existing study program European Master in Adult Education (EMAE), to widen the access to this study program to practitioners, and to build up a network of European Centres of Research and Doctorates in AE. The EMAE Joint Degree Program is offered in 10 universities from nine countries: Kaiserslautern, Florence, Barcelona, Dublin, Brno, Kaunas, Pecs, Timisoara, Belgrade and Würzburg.

EMAE has been running since 2006, and its curriculum has been updated according to new developments in the labour market and to changes in the competency profile of adult learning professionals (ALPs). It includes different fields of topics in $\mathrm{AE}$, meant to cover different roles of adult educators, from that of teacher/ trainer to those of evaluator of competencies, counsellor, manager, public officer, curriculum developer, etc. (Nuissl, 2010).

The international dimension of the EMAE curriculum is ensured by its concept. "International" means in this context a common perspective of European countries regarding curriculum, learning outcomes and relations to the common labour market. "Internationalization" is defined as all activities to develop the study programs in an international context, in their content as well as in their structure.

The collaborating universities agreed on a common core-curriculum (covering 70 ECTS out of the 120 ECTS), agreeing to use common learning resources (series of study texts, online learning platform, summer academies - see www. esrale.org), to recognize mutually learning outcomes, follow comparable quality assurance mechanisms and evaluation criteria, and emphasize methodologically comparative aspects. The aim is to increase the students' international awareness, their intercultural competences and their engagement with global issues as an overall learning outcome (Van Swet, 2012; Gregersen-Hermans, 2015). The fact that universities all over Europe are developing transnational study programs clearly contributes to an enhanced professionalization in AE. In this way, not only is the professionalization of young researchers supported, but also the development of scientific knowledge in the field of AE (Nuissl, 2010). 
Within the European Higher Education Area, a lot of Joint Programs in other disciplines have been already implemented, and the lessons learned from such attempts are reflected and largely disseminated through transnational studies or good practice handbooks (Aerden, 2014; Pereira, 2015). In the field of education, however, there is little experience in this regard, as education is a nationally and culturally specific field, linked to the history and societal developments in each country, and this is fundamentally true in the field of adult education. Therefore, it seemed useful for us to ask the coordinators of the master program in the partner universities about their motives and expectations in joining such attempt on more of a "meta-level". What follows are their opinions and insights, based on our research question: "What is the added value of internationalization in universities` AE programs?"

\section{Internationalization and Professionalization}

Educational policies that promote and support internationalization of higher education institutions (HEI) are becoming more articulated both at national and European level. The Bologna Process and the efforts for building up the European Higher Education (and Research) Area (EHEA) have strongly contributed to intra-European internationalization, with different tools being put in place to foster this trend, from the ECTS system to the financial support of the Erasmus+ Program, or to monitoring and evaluation studies (see Erasmus Impact Study, 2014). Furthermore, the recommendations of the European Commission (EC, 2013) stress the importance for the member states of designing national strategies for internationalization of higher education, emphasizing not only the goals to be considered (i.e. "international student and staff mobility; internationalization and improvement of curricula and digital learning; strategic cooperation, partnerships and capacity building"), but also the responsibilities of different actors and the needed resources (Matei, 2015). In spite of the European recommendation, only 16 countries out of 48 have adopted such national strategies by 2015 (EC, 2015).

At the institutional level, international activities and concerns for expanding them are reported by most of HEIs worldwide (Egron-Polak, 2014; Guri-Rosenblit, 2015). As institutions now increasingly implement internationalization, "they should be clear and transparent about why they are undertaking a particular initiative, how it relates to their academic mission and values, and what mechanisms can be put in place to avoid possible negative consequences" (Guri-Rosenblit, 2015). It is not only the quantity that counts, 
but also - and predominantly - the quality of international activities and the way they are embedded in the universities' culture and strategy (Tadaki, 2013; Knight, 2013; Sawir, 2013; Beelen, 2015). Thus, universities increasingly try to compete in international rankings and they enhance their research capacity and their quality and diversity of curricula through international partnerships. The increased efforts towards international activities are determined by various factors (deWit, 2015).

Improving a "comprehensive" strategy for internationalization (Beelen, 2015) and its implementation in the universities involves acting at all organizational levels from strategic international consortia for teaching and research to curricula and services. The different managerial solutions for cross-border cooperation, like opening branch campuses abroad, setting up international joint degree programs, partnerships for research projects, or 'virtual mobility' (Matei, 2015; Knight, 2013) are to be complemented by guaranteed recognition of degrees, with corresponding mechanisms of quality assurance (Guri-Rosenblit, 2015), with formal regulations and procedures for grading systems and comparability. New forms of internationalization, like the massive open online courses (MOOCs), co-founded or co-developed HEIs, franchise university or different forms of distance learning (Knight, 2016), allow enhancing competitive advantage, demonstrate excellence in different areas, extending activities to international markets (EC, 2015, 2013; Guri-Rosenblit, 2015).

The impact studies of internationalization activities (EU, 2014) show very encouraging outcomes, for students, staff, HEIs` engaging in such activities, as well as for the quality, variety and quantity of research activities. Thus, "beneficial effects on the quality of teaching could be observed by $81 \%$ of academic staff, together with multidisciplinary and cross-organizational cooperation (81\%)" (EU, 2014). Students enrolled in international study programs are more likely to develop an international awareness, understanding, and mind-sets, a more advanced intercultural sensitivity, competence, and expertise (Sawir, 2013), leading to a better "tolerance for ambiguity, behavioural flexibility, communicative awareness, respect for others and empathy" (Perry, 2011) being more open to work and live in different international contexts (EU, 2014).

However, the level of intercultural competence of the students is not increasing just by exposing them to studies in a foreign language, by having international students on campus or ensuring their mobility abroad (Gregersen-Hermans, 2015). More important than the social interactions between international students is to "add internationalization of pedagogy and assessment across the whole curriculum” (Vidovich, O`Donoghue \& Tight, 2012, p. 286). Through 
an emphasis on international literature, comparative studies, multicultural tasks, transnational teamwork, guest lectures, digital learning etc. (Beelen, 2015; de Wit, 2015) students can come closer to international developments and practices. This way, internationalization at home happens, as "purposeful integration of international and intercultural dimensions into the formal and informal curriculum for all students within domestic learning environments" (Beleen, 2015).

In setting up and running international studies, the main emphasis is on the benefits and challenges for the students and for the institution. The academic staff who have to implement such programs are seldom investigated (Doiz, 2013). Therefore, the data we are going to present, coming from interviews with the academic staff (mainly with the program coordinators), is aimed at exploring their motives for building such international study programs in their universities as well as their reflections on the experience of running these.

\section{Exploration Method}

In this paper the views of the partners involved in developing the Joint Master Program in AE are explored. The main question of this analysis is: "What is the added value of internationalization in universities 'Adult Education programs?", as has been formulated above. "Added value" is defined as going beyond the value of the national strategies of academic teaching and learning. The partners were interviewed with the purpose of finding out about their motivation and about the short and long term expectations for joining a program like ESRALE. Questions were also asked about the obstacles and difficulties in designing and implementing this joint program.

We surveyed ("interview" suggests talking rather than writing) all the ten university partners involved in the project: Germany (two universities), Ireland, Lithuania, Spain, Italy, Czech Republic, Hungary, Romania and Serbia. The survey consisted of ten questions on the main topics of interest: motivation, benefits, perspectives, obstacles and added value. The questions were open, given in a written form. The answers were analysed and categorized inductively, by structuring the items and factors mentioned in the interviews. The numbers following the citations indicate the interview partner and the paragraph in which they occur.

The character of this approach is explorative (Silverman, 2011), giving basic information for further representative research, for management of the universities, academic staff, and policy makers. The topics and items mentioned are presented in the following five paragraphs $(\mathrm{a}-\mathrm{e})$. 


\section{Data analysis}

\section{a) Interest in international work}

Nowadays internationality is a basic criterion in each evaluation of public institutions, including universities. Another question is whether there is also an interest in international work. But it is interesting to look more closely at the kind of motivation and interest being expressed.

An important factor in motivation is the scientific community. "I feel I am a member of a strong community of knowledge exchange in $\mathrm{AE}^{\prime}(4,2)-$ mainly in the field of AE. More concretely this means "sharing experiences" and "learning from colleagues" $(1,3)$ as well as strengthening the research base in $\mathrm{AE}$ $(1,2)$. This might also include common projects and work-plans with a common perspective $(2,4)$.

Underlined was a specificity of AE: the wide range of topics it deals with. It encompasses "a wide range of professional groups, including, e.g., people working in health, urban development, community education, higher education, work-based training" $(1,2)$, people working with different target groups (like age groups) and in different regions $(2,2)$. "There are some scarce subjects which can be found at other universities and in other countries, like social work related to AE or education with special groups like Sinti and Roma" $(7,3)$. furthermore: "In the context of the European crisis the contact between young people is important in ensuring peace in Europe - a best practice for peace is the development of empathy for each other" $(2,4)$. Related to this the variety of knowledge in different fields and the use of different and useful methods of research was highlighted $(5,2)$.

Some of the partners mentioned the different backgrounds to scientific approach in andragogy, either in a historical or in a theoretical direction. "The issue of andragogy is different indeed from that of $\mathrm{AE}$, and you can learn a lot from the historical perspective" $(6,3)$. The different focus of AE in Western, Southern and Eastern of Europe are also underlined as a source of broader understanding, mainly quality, institutionalization, commitment, laws and structures $(1,1 ; 3,1 ; 7,2)$.

Other motives for joining ESRALE: "I wanted my university to become part of a scientifically distinguished community of research in adult learning and education" $(8,2)$; interesting are "particular aspects of curriculum development in AE master programs" $(6,2)$. And finally, this is considered to be a very strong factor in "improving the studies of andragogy" $(9,2)$. 


\section{b) Relevance for the University}

When it comes to relevance for participating universities there is one vote "unison": Internationalization is an important part of the strategy of the whole university - actually in all countries. There were comments like "the internationalization is one of the main goals of the University of X." (4,2), our university has "a strong emphasis on an international perspective in adult and continuing education" $(2,2)$, "we have been involved in many international projects for the research and contribution on education" (7.1). Or, in general words: "A European and global perspective are important and the opportunity to strengthen existing European connections" $(1,1)$.

Beside this general support pro-internationalization, there are other special points of relevance. One is the fitting of ESRALE to the concrete process of curriculum construction in the respective university: "We are right in the middle of the development of the curriculum for our own master program and would like to shape it in a way that it is compatible with this international study program" $(8,1)$. The internationality is also seen as an improvement of quality: "international programs are definitely raising the quality of our program through incorporating innovative aspects being currently used all over Europe" $(6,4)$.

Particularly in universities that have not been in the European Union for very long, the internationalization implied in the meaning of "going into Europe" plays an important role. "European study and research is a part of our university strategy. The idea to join the common area of European scientific research and to develop liaisons with the global scientific community is stressed in our university statute" $(3,2)$ or, in other words: "Great, because for a long period of the last decades only some professors had individual contacts with colleagues from different countries and universities, could meet in conferences and projects: "This is one of the ways to come back into Europe and the European educational space" (9, 3). In another case, internationalization is seen as something to be developed, it is felt not to be strong enough and in a need of fostering. "We need to build up a better international program, to have more international elements in our curriculum, this is nowadays a factor of excellence" $(5,2)$.

It is pointed out very firmly that participation in an international project has an impact on the image of the (AE) unit inside the university as well as an effect on the international activities of other departments. "Seeing the fact that our level of quality and discussion is raising since we are more and more internationalized, other departments started to follow our example" $(6,3)$. The presence of guest professors via ERASMUS and of foreign students is a challenge not only for the AE units, but for the whole environment: "Some colleagues try to avoid 
the communication with foreign colleagues in another language, but others are motivated and eager to learn and to enrich their activities" $(2,5)$.

The relevance of internationalization for the university depends partly on the status of the AE department. But even small units can create innovative approaches to international connections. "We have only a small unit for AE in the university, but already many colleagues asked how it works and how it is possible to implement an international part in the program" $(6,3)$. For the universities it is not only - in general - part of the constitution, but also part of evaluation and renommée.

\section{c) Benefits for the participants}

Participants in an international program like ESRALE are mainly teachers and learners. For both of them the main benefit is considered to be a broader and deeper competence and knowledge in the field of AE. "Students and teachers...... have a benefit of accumulating knowledge around adult learning and education with European perspective put into a comparative dimension" $(8,4)$.

This is also seen in a wider view: "Students, teachers and practitioners have a strong advantage in the accumulation of a deep knowledge of adult learning and education in the European context and ease the comparative analysis and the exchange of best practice" $(4,3)$. Here it is not only the study and research which counts, but also the exchange of good and best practice amongst the countries. Close to this point of view is the link to policy and practice, being stressed in the following: "The main benefits provide valuable links to action-orientated research to both policy and practice in $\mathrm{AE}$ and related areas" $(1,7)$.

Looking at the university level the opportunity for a broader offer is underlined -for topics, of teachers, of insights from different perspectives. The opportunity to learn a foreign language (English), with professional terms is also mentioned: "With the international collaboration is enlarged the offer of subjects (at the graduate level) and $\mathrm{PhD}$ program on $\mathrm{AE}$ done with a European dimension" $(7,7)$. Not only the variety of subjects is underlined, but also the wider access to teaching and research methods: "This open and flexible teaching, away from frontal lectures, was not familiar at our university, it is a challenge for all our professors" $(6,8)$ and "our approach in educational sciences is more driven by theoretical reflections - with the international discussions comes a higher impact on empirical research and evidence" $(4,6)$.

For the teaching professors a big benefit is seen in mobility: "By teaching in another university we learn about other cultures of education, we get in touch 
with other professors, we can reflect more about the rules of academic life" $(5,6)$. The increase in knowledge about the different learning strategies in different cultures seems to be of high value: "In comparing my students to the students here I can see a more motivated and concretely focused approach" $(3,4)$. In general, the comparison with the situation in other universities in other countries allows a better understanding of the situation: "All involved people have the opportunity to contrast and mirror their own perspectives, the discussion with international fellows makes the own structures and understandings visible and clearer - furthermore, it opens the possibility to think in different and new ways" $(2,5)$.

An important benefit for the teachers as well as for the students is the international networking, which develops from the common working activities. "It is the younger generation which has to fill the European idea with social contacts and common topics, and this starts in international programs" $(7,3)$. What is more: "It is our duty as academic teachers, to provide the opportunity for the younger generation to build up international networks, not only teaching them about subjects. This is as important as supporting their way in the labor market" $(5,5)$.

\section{d) Obstacles against internationalization}

As it could have been expected there are obstacles seen in the availability of finances, time given and the necessary resources. "Financial resources are the main obstacle - not enough for travel, neither for teaching " $(2,6)$ - followed by the comment: "Therefore, several sources of funds can be used and have to be used, if there is time and knowledge how to get them " $(2,7)$. But - beside this comment - the question of resources is not given priority; people working in education are used to being modest and aware of limitations in resources. There are other problems and obstacles underlined.

The upmost one is the diversity of universities, study programs and educational approaches. "I think the most obvious obstacle is the different environments in the HE (Higher Education) system of the countries. They make it very difficult to implement a joint collaboration, e.g. the development of a joint degree" $(8,4)$. The special regulations in each university (access, curriculum, exams, etc.) are mentioned as difficult barriers for developing a common study program. Even in bilateral contracts the hindering details of these regulations are hard to resolve.

It is not only the system of regulations in each university, but also the way they are interpreted and flexibly adapted. Here administration plays an important role. "Bureaucracy - carried out by the administration - can help to implement a 
common program, but it can also be a severe obstacle; more often the latter is the case" $(4,5)$. It is not necessarily bad will that leads to a bureaucratic obstacle: "Administrations have not got enough experience in the organization of international mobility and the work in this type of project" $(9,5)$. There is hardly any training of people working in administration for international affairs, competences and very often sensibility is missing. Not only this: "It can't be expected from administrators to be competent in the subject (here: $\mathrm{AE}$ ) and in languages as well as in their main business, organization and administration" (5,3). Most universities nowadays have an international office, but they work very differently and with different tasks and understandings.

International work in the field of education has not really been systematically developed so far. So even in universities with quite a high level of international connections the departments of education are still in the period of learning. "We have many international contacts in our technical disciplines, also in psychology and sociology, but our experience in education is very limited" $(5,4)$. This might be even more in so in AE: "Another obstacle is the low academic recognition and support of professionalization of $\mathrm{AE}$ in some member states together with a strong majority of focus towards labor market needs and employability in the context of $\mathrm{AE} "(7,4)$.

There are also obstacles in the technicalities development of a joint study program. The common time of the participating ten universities for teaching (semester or trimester structure) per year is only 1,5 months, in other words: six weeks. Since several of the common core seminars and lectures are online for all participating students, the workload in these six weeks (November and May) for the students is tremendous. "It is really a puzzle work to find time slots fitting for all partners and all needed subjects, so the management of the network of partner universities is facing hard difficulties" (5.8).

Regarding language (in the partnership and the common courses English is used) the opinion is heterogeneous. "English as language is not the obstacle, but the fitness of students to interact, talk and study in this language" $(2,6)$. The low skills in this language are mainly seen in bigger countries such as Germany, Spain and Italy, less in smaller countries. And there has been a big improvement in the last decade: "The generation of students enrolling in studies now, have a higher competence in foreign languages, mainly English, than the student cohorts before. This seems to be due to the school curricula, but also a higher mobility and an intensive use of internet communication, which is requiring mainly English language capabilities." $(6,6)$. But even the low skills in English language 
are not a real obstacle for students. Quite often just the contrary: students are using the chance to improve their English competences by attending classes in this language. The real obstacle lies in attitude and the extra effort required to adapt to different challenges.

This motivation is less evident amongst the teachers and professors. Here as well there exists a difference in language skills between the cohorts: the older generation of teachers in pedagogy is - on average - less qualified than the younger generation. "Only few colleagues of the staff are participating in the international courses as teachers because of language reasons, mostly the younger ones" $(5,2)$, and: "It is one thing to have a small talk in English, another one to teach in this language; pedagogical topics depend a lot on the elaborated language being used" $(6,5)$. In contrast to the students, the professors are not prepared to improve their English competences in the seminars, by teaching. "It is not only a question of delivering content and expertise, but also self-understanding" $(8,4)$.

The limited number of colleagues involved in international activities of the university and the lack of commitment of others is seen as a problem of sustainability: "When I leave here, I'm not sure whether my colleagues will continue" $(3,1)$. It is also an aspect of networking: "Our international activities are built up in my network; I tried to involve more colleagues, but this is socially seen like closed shop, at least sometimes" $(7,6)$.

\section{e) Added value in a long term perspective}

The "network and sustainable partnership between young people in Europe" $(2,6)$ is seen as a valuable and important result coming from common studies and research projects.

The added value is seen mainly in the following aspects:

- Better understanding of AE in its societal role, in own country, as well as in others;

- Learning more topics of $\mathrm{AE}$ and their specific relevance in different countries;

- Having more and better skills in doing research work from a comparative perspective;

- Understanding the meaning of the European idea and its impact on daily life; 
- Knowing more institutions and best practice in $\mathrm{AE}$ in other regions;

- Sharpening the profile and concept of professional adult educators;

- Making AE nationally and internationally more visible;

- Enhancing the image and awareness of the importance of AE.

In the long term the initiative and approach of ESRALE could lead to a strong and sustainable European doctoral and master program, being offered at in diverse universities all over Europe. There would also be a possibility of enlarging the experience to other universities in Europe and in other continents. Via ESRALE AE research centers can create an international network, and in consequence the quality and outreach of research in this field can be improved. In the future, a joint degree at master level and doctoral level can stabilize the discussion on professionalization in this field.

\section{Conclusions}

Internationalization is a very commonly used word nowadays, in attempting to address the need for diversity and wide ranging perspectives. However, it is a vague term, not really concretely defined or definable. On the other hand, inside European Union this term has a real dimension, defining the common activities in several political and cultural fields. The soft and open policy making in higher education and $\mathrm{AE}$ has obvious impacts - benchmarks in participation, common surveys and monitoring studies, quality standards, levels of the EQF, and many more developments can be seen. Also, within the European Higher Education and Research Area, the internationalization agenda is getting stronger and stronger.

Given such a dynamic and convergent move towards internationalization, the consortium involved in the ESRALE project is an example of international partnership, aimed at enhancing the international dimension of research and teaching in adult education. The joint master program, the initiative of organizing a forum to share experiences and practices, both within academic exchanges and research collaboration, building rich know-how and resources for learning and researching, are the aims confirmed by the program's coordinators in the partner universities as rationale for joining the consortium and building such a joint study program. Such aims are in line with the rationale for setting up international consortia, as described by Tadaki (2013), thus increasing the academic prestige.

Setting up such consortia in $\mathrm{AE}$ was possible due to the fact that over the past ten years staff working in this field became important for European policy 
making in AE and LLL (Sava, 2014), and the need to professionalize is more and more emphasized (EC 2012, 2013b, CEDEFOP 2013), as layer of increased quality in $\mathrm{AE}$, and better support for the learning of adults.

Apart from the national long-termed activities of the partners to reach a higher degree of professionalization in $\mathrm{AE}$ in their respective countries, they agree on the necessity of working together, to join together at a European level and to link the efforts and resources in the study program. The motivation is evidently strong, the wish for internationalizing the research and curriculum is stated, the implementation of European elements in the study programs is proceeding. The added value is mainly seen in:

- A wider horizon and a better understanding by the students;

- European labour market perspectives;

- A collaborative scientific work of PhD students and academic staff;

- An improvement of the range of the discipline and topics, resources and scientific know-how by combining small units to a network;

- A higher reputation of the discipline and the respective university.

On the other hand, something also evident in the interviews is that there are difficult obstacles of different kind. There are generic obstacles in implementing a common study program (time, delivery mode, language etc.), but also strong formal obstacles under legal, financial and administrative aspects. However, the obstacles underlined can be found in diverse research on internationalization of study programs, irrespective the disciplinary field (Van Swet, 2012; Guri-Rosenblit, 2015). There is an obstacle in the labour market in the area of acceptance of not yet known competences and qualifications, too. It is mainly here that this is evident: the process of internationalization takes time. This is true not only as regards the efforts and resources needed to implement multilingual or international programs, but also as regards readiness of the players involved: students, academic, administrative and managerial staff in universities. The data, from this perspective, is consistent with the data presented by Doiz (2013) while interviewing participants in university life, highlighting the "inherent complexities of a multilingual university and the many challenges faced", both in terms of accepting and functioning of an English-medium instruction, and in terms of additional support from the university to implement international studies.

As additional findings of our explorative study can be noted there have to be coherent efforts of states and universities to overcome the inner organizational obstacles, and further research is needed on the reality of working in adult education in a European and international dimension. 


\section{References:}

Aerden, A. (2014). Joint Programme Checklist: inspired by quality assurance. European Consortium for Accreditation in higher education.

Beelen, J., \& Jones, E. (2015). Conceptual is in internationalization of the curriculum - Redefining Internationalization at Home. In A. Curaj, L. Matei, R. Pricopie, J. Salmi, \& P. Scott (Eds.), The European Higher Education Area Between Critical Reflections and Future Policies (59-76). Springer Open. http://www.springer.com/ us/book/9783319187679

Bernhardsson, N., \& LatTKe, S. (Eds.), (2011). Core Competencies of Adult Learning Facilitators in Europe. Findings from a Transnational Delphi Survey. Retrieved from: asemlllhub.org/fileadmin/www.dpu.dk/ASEM/events/RN3/QF2TEACH_ Transnational_Report_final_1_.pdf

Buiskool, B. J., Broek, S. D., Van Lakerveld, J. A., Zarifis, G. K., \& Osborne, M. (2010). Key competences for adult learning professionals. Contribution to the development of a reference framework of key competences for adult learning professionals. Project Report. Research voor Beleid, Zoetermeer, Netherlands. Retrieved from: http://ec.europa.eu/education/more-information/doc/2010/keycomp.pdf

CEDEFOP (2013). Trainers in continuing VET: emerging competence profile. Luxembourg: Publications Office of the European Union. Retrieved from: http://www.cedefop. europa.eu/EN/Files/4126_en.pdf

Chisholm, L. (2013). Exploring the future of lifelong learning: advocacy, research and foot printing. International Review of Education, 59, 373-382.

Doiz, A., Lasagabaster, D., \& Sierra, J. (2013). Globalisation, internationalisation, multilingualism and linguistic strains in higher education. Studies in higher education, 38(9), 1407-1421.

Egetenmeyer, R., \& Nuissl, E. (Eds.), (2010). Teachers and Trainers in Adult and Lifelong Learning - Asian and European Perspectives. Frankfurt am Main: Peter Lang.

Egron-Polak, E., \& Hudson, R. (2014). Internationalization of higher education: Growing expectations, fundamental values (IAU 4th Global Survey). International Association of Universities. Retrieved from: http://www.iau-aiu.net/sites/all/files/ IAU-4th-GLOBALSURVEY-EXECUTIVE-SUMMARY.pdf

EuROPEAN COMMISSION. (2012). Rethinking education: investing in skills for better socioeconomic outcomes. Strasbourg: European Commission. Retrieved from: http:// www.cedefop.europa.eu/EN/Files/com669_en.pdf

European Commission. (2013). European higher education in the world. Brussels: Retrieved from http://eur-lex.europa.eu/legal-content/EN/TXT/PDF/?uri=CELEX :52013DC0499\&from=EN

European Commission. (2013b). Thematic Working Group on Quality in Adult Learning. Final Report. Oct. 2013. Retrieved from: http://ec.europa.eu/education/policy/ strategic-framework/doc/2013-quality-final_en.pdf 
European Commission. (2015). The European Higher Education Area in 2015: Implementation Report Bologna Process. Luxembourg: Publications Office of the European Union. Retrieved from: http://eacea.ec.europa.eu/education/eurydice/documents/thematic_reports/182EN.pdf

European Union. (2014). The Erasmus Impact Study. Effects of mobility on the skills and employability of students and the internationalization of higher education institutions. Brussels: European Union. Retrieved from: http://ec.europa.eu/education/ library/study/2014/erasmus-impact_en.pdf

Gregersen-Hermans, J. (2015). The Impact of Exposure to Diversity in the International University Environment and the Development of Intercultural Competence in Students. In A. Curaj, L. Matei, R. Pricopie, J. Salmi, \& P. Scott (Eds.), The European Higher Education Area Between Critical Reflections and Future Policies (73-92). London: Springer.

Guri-Rosenblit, S. (2015). Internationalization of Higher Education: Navigating between Contrasting Trends. In A. Curaj, L. Matei, R. Pricopie, J. Salmi, \& P. Scott (Eds.), The European Higher Education Area Between Critical Reflections and Future Policies (13-26). Springer Open. http://www.springer.com/us/ book/9783319187679

Jütte, W., Nicoll, K., \& Salling-Olesen, H. (2011). Professionalization - the struggle within. European Journal for Research on the Education and Learning of Adults, 2(1), 7-20. Retrieved from www.rela.ep.liu.se

Knight, J. (2013). The changing landscape of higher education internationalisation-for better or worse? Perspectives: Policy and practice in higher education, 17(3), 84-90.

Knight, J. (2016). Transnational Education Remodeled: Toward a Common TNE Framework and Definitions. Journal of Studies in International Education, 20(1), 34-47.

Kondratjuk, M. (2009). Professionals in AE: The Omnipotent Profile Adult Educators. Journal of Educational Sciences, 1(19), 37-42. Retrieved from www.resjournal.uvt.ro

Lattke, S., Popovic, K, \& Weickert, J. (2013). Curriculum for global adult learning and education, Bonn: DVV International and German Institute for Adult Education. Retrieved from http://www.iiz-dvv.de/files/curriculum_globale_eng_fin.pdf

Lattke, S., \& Jutte, W. (Eds.), (2014). Professionalisation of Adult Educators - International and Comparative Perspectives, Frankfurt am Main: Peter Lang

Matei, L., \& Iwinska, J. (2015). National Strategies and Practices in Internationalization of Higher Education: Lessons from a Cross-Country Comparison. In A. Curaj, L. Deca, E. Egron-Polak, \& J. Salmi (Eds.), Higher Education Reforms in Romania Between the Bologna Process and National Challenges (205-226). London: Springer.

Nijssen, A. (2008). ALPINE-Adult Learning Professions in Europe: A Study of the Current Situation, Trends and Issues. Project Report. Research voor Beleid, Zoetermeer, Netherlands. Retrieved from http://ec.europa.eu/education/more-information/ doc/adultprofreport_en.pdf

Nuissl, E., \& LATtKe, S. (Eds.), (2008). Qualifying adult learning professionals in Europe. Bertelsmann Verlag. 
Pereira, M. (2015). Joint Programmes from A to $Z$, The Hague: NUFFIC. Retrieved from https:/www.nuffic.nl/en/library/joint-programmes-from-a-to-z-a-referenceguide-for-practitioners.pdf

Nuissl E., \& SAva, S. (2010). Qualifying for European Adult Education. In S. Medić, R. Ebner, \& K.Popović (Eds.), Adult Education: The Response to Global Crisis, Strengths and Challenges of the Profession (73-80), Beograd: Čigoja štampa.

Perry, L. B., \& Southwell, L. (2011). Developing intercultural understanding and skills: Models and approaches. Intercultural Education, 22(6), 453-466.

SAvA, S. (2011). Towards the professionalization of adult educators. Andragoške studije, (2), 9-22.

SAVA, S. (2014). From 'innovation to quality': the topic of professionalisation for adult learning staff in selected European policy documents. In G. K. Zarifis, \& M. Gravani (Eds.), Challenging the 'European Area of Lifelong Learning' - A Critical Response (147-156). London: Springer.

SAWIR, E. (2013). Internationalization of higher education curriculum: the contribution of international students. Globalization, Societies and Education, 11(3), 359-378.

Silverman, D. (2011). Interpreting qualitative data, $4^{\text {th }}$ edition, London: Sage

TADAKI, M., \& TRENEWAN, C. (2013). Reimagining internationalization in higher education: international consortia as a transformative space?. Studies in Higher Education, 38(3), 367-387. Retrieved from http://www.tandfonline.com/doi/full/10.1 080/03075079.2013.773219

Van Swet, J., Armstrong, C.A., \& Lloyd, C. (2012). International collaboration as a patchwork quilt: experiences of developing collaborative practice and research in an international master programme, Professional Development in Education, 38(4), 647-661.

Vidovich, L., O`Donoghue, T., \& Tight, M. (2012). Transforming university curriculum policies in a global knowledge era: mapping a "global case study" research agenda, Educational Studies, 38(3), 283-295

DeWit, H., \& Engel, L. (2015). Building and deepening a Comprehensive Strategy to Internationalise Romanian Higher Education. In A. L. Curaj, E. Deca, E. EgronPolak, \& J. Salmi (Eds.). Higher Education Reforms in Romania Between the Bologna Process and National Challenges (191-204). London: Springer. 
Ekkehard Nuissl ${ }^{5}$

Tehnički univerzitet u Kajzerslauternu, Nemačka

Simona Sava ${ }^{6}$, Anca Luştrea ${ }^{7}$

Zapadni univerzitet u Temišvaru, Rumunija

\section{Internacionalizacija istraživanja i studija u oblasti obrazovanja odraslih}

Apstrakt: Postoji velika potreba za formalnom provizijom profesionalizacije edukatora za rad sa odraslima na akademskom nivou (Istraživanje za politiku, 2008; Evropska komisija, 2013b; CEDEFOP, 2013). U ovom radu se sagledavaju stavovi kolega sa deset univerziteta iz devet evropskih zemalja koje su uključene u izradu zajedničkog Evropskog mastera iz obrazovanja odraslih (EMAE) i Evropskih doktorskih studija za obrazovanje odraslih, čime se stvara najveća mreža za profesionalizaciju obrazovanja odraslih na evropskom nivou. Intervjuisali smo kolege sa svrhom otkrivanja njihove motivacije, očekivanja, dodatne vrednosti programa za njihove univerzitete, kao i ishoda i koristi pridruživanja takvom konzorcijumu. Takođe smo želeli da saznamo i o preprekama i poteškoćama u kreiranju i implementaciji zajedničkih programa. Njihova razmatranja i iskustva mogu da posluže kao inspiracija drugim univerzitetima zainteresovanim za pridruživanje konzorcijumu ili za otvaranje sličnih programa.

Ključne reči: globalizacija i međunarodno visoko obrazovanje, profesionalizacija, obrazovanje odraslih, zajednički programi, međunarodna saradnja u oblasti visokog obrazovanja

\footnotetext{
${ }^{5}$ Dr Ekkehard Nuissl je profesor na Tehničkom univerzitetu u Kajzerslauternu, Nemačka.

${ }^{6}$ Dr Simona Sava je profesor na Katedri za nauke o obrazovanju, Zapadni univerzitet u Temišvaru, Rumunija.

${ }^{7}$ Dr Anca Luştrea je docent na Katedri za nauke o obrazovanju, Zapadni univerzitet u Temišvaru, Rumunija.
} 